\title{
Limity českého pojetí multikulturní výchovy
}

\author{
Andrea Preissová Krejčí, Jana Máčalová
}

\begin{abstract}
Abstrakt: Studie je kritickou reflexí českého pojetí multikulturní výchovy. Na př́kladu dlouhodobě uplatňovaného multikulturního vzdělávání v USA objasňujeme př́liš úzké chápání rozsahu a obsahu multikulturní výchovy na českých školách a poukazujeme na problematické momenty, které nejen že neumožňují zdárné naplňování cílů multikulturního vzdělávání, ale dokonce mohou posilovat stereotypní uvažování a vytvářet xenofobní až rasistickou atmosféru ve školních třídách. Za významné činitele $v$ tomto ohledu považujeme jednak osobnost pedagoga, jednak $v$ českém prostředí běžnou konceptualizaci slovníku charakteristického pro rasistická a nacionalistická hnutí v řadě učebnic.
\end{abstract}

Klíčová slova: multikulturní výchova - ČR, multikulturní výchova - USA, multikulturalismus, pedagog, rasa, etnicita

\section{1 ÚVOD}

Když byl v rámci reformy školského systému podle Národního programu rozvoje vzdělávání $k$ 1. září 2007 do praxe plošně zaveden rámcový vzdělávací program (RVP) pro základní vzdělávání a k 1. zárí 2009 RVP pro gymnázia, stala se idea multikulturalismu, zejména $v$ podobě průřezového tématu multikulturní výchovy, povinnou součástí vzdělávání na českých školách a v současné době je také aktuálním tématem sociální pedagogiky, nebot' podle strategie primární prevence MŠMT mezi základní typy rizikového chování patří mj. homofobie, rasismus, intolerance či xenofobie (Procházka, 2012, 7172,141 ). Vytvoření platformy pro rozvoj tolerance a empatie, tedy prostoru pro diskuzi většiny s menšinami, je v souladu s cíli sociální pedagogiky nanejvýš žádoucí (srov. Gulová, 2012, 12), avšak dokument zastřešující danou reformu pedagogům nedal do rukou nástroje, pomocí nichž by bylo možné cíle multikulturní výchovy ve výuce naplnit. Jinými slovy, neexistuje jednotné pojetí toho, jak multikulturní výchovu vyučovat. A tak učitelé při realizaci multikulturní výchovy do značné míry dosud navazují na národopisnou tradici, národní uvědomění a folklor a nejsou $s$ to reflektovat kritické rozpravy probíhající na téma multikulturalismu a multikulturní výchovy v zahraničí, zejména v USA. Jak uvádí také Tomáš Hirt, při multikulturním vzdělávání se „nereflektovaně uplatňuje převážně model vycházející z dřevních dob multikulturalistického projektu včetně přehmatů a problematických konsekvencí" (Hirt, 2005, 10). Zavádění multikulturní výchovy do škol včetně rizik s tím spojených jsme se věnovali v našich předchozích pracích (nejnověji viz např. Preissová Krejčí, 2014, 2013; Preissová Krejčí et al., 2012 atd.), za cíl této studie si klademe poukázat na v současné praxi podceňované možnosti výchovy $\mathrm{k}$ multikulturním souvislostem v České republice, na možnosti vyšší míry participace kritického multikulturalismu a na potřebu překlenout folkloristický přistup obsahově bohatším pojetím multikulturalismu po vzoru anglosaské tradice. Vycházíme přitom z rozsáhlé analýzy prací amerických odborníků na tuto problematiku (např. Banks, Banks, 2010; DomNwachukwu 2010; May, Sleeter, 2010; Sleeter, Grant, 2009; Molnar, 2006), stejně jako z důsledného studia literatury české (v této studii zj. Hirt, Jakoubek, 2005; Kosek, 2011; Morvayová, Moree, 2009) či česky dostupné (především Eriksen, 2008, 2012), a navazujeme na své předchozí bádání v této oblasti uskutečněné v posledních letech včetně výzkumných šetření, která jsme ve vztahu $\mathrm{k}$ tomuto tématu realizovali a na něž se $v$ textu průběžně odkazujeme, jakož i na výzkumy jiných autorů. Jak na př́iklad předznamenává výzkumné šetření Barbory Viktorové, pedagogové v České republice mají tendenci vnímat multikulturní výchovu zúženě, když v rámci ní akcentují pouze 
národnostní, resp. etnickou, méně již kulturní, odlišnost, nebo ji dokonce považují výhradně za nástroj integrace romské menšiny (Viktorová, 2013, 42-43). Přitom multikulturní výchova založená na pouhé prezentaci jednotlivých etnik či kultur, které jsou zastoupeny na našem území, může vést nikoli k nabourávání, ale naopak k utvrzování stereotypních představ o příslušnících těchto odlišných skupin a skrze přehnané poukazování na jejich rozdílnost přispívat $k$ jejich symbolickému vyčlenění, nebot' „,nereflektovaně podporuje předpoklad, že je možné stanovovat a popisovat objektivní hranice kultur, etnik, národností a vybraných skupin podle předem šablonovitě stanovených a údajně univerzálně platných charakteristik" (Morvayová, Moree, 2009, 13). V důsledku toho je v nemalé míre v prostředí českých škol patrná konceptualizace slovníku charakteristického pro rasistická a nacionalistická hnutí, podpořena $\mathrm{mj} . \mathrm{v}$ učebnicích. Vzhledem $\mathrm{k}$ důsledkům, které takto vedená multikulturní výchova má na př́slušníky menšin, považujeme $v$ této studii za důležité věnovat prostor také problematice pojící se s dělením lidí na rasy.

Srovnáním přistupů $\mathrm{k}$ multikulturalismu ve vzdělávání ve společnosti české, která je víceméně etnicky homogenním státem, přestože tak tomu v minulosti nebylo vždy (srov. Preissová Krejčí, 2014, 22), a ve společnosti tradičně multikulturní, jakou je např. společnost americká, přicházíme k zjištěním, jejichž rozboru věnujeme následující raádky. Jedním z nich je skutečnost, že multikulturní výchova není pouze a jen o polemice nad soužitím majority $s$ problémovou minoritou, $v$ českém prostředí hojně přetavovanou $v$ tzv. romskou otázku.

Praktické uplatňování spravedlivého přístupu $\mathrm{k}$ jinému a diverzitnímu v českém prostředí zaostává za státy západní Evropy či Severní Ameriky. V České republice existuje vyšší míra nespravedlnosti, a to jak ve společnosti obecně, tak v př́stupu ke vzdělávání, která by skrze větší vnímavost budoucích generací, které $\mathrm{k}$ ní budou systematicky vychovávány i prostřednictvím multikulturní výchovy, mohla být odstraňována. Společnost nepřistupuje rovně $k$ lidem různého pohlaví, různého původu či etnicity, pocházejícím z různých společenských vrstev, z různého domácího intelektuálního prostředí, jak bylo zjištěno také v rámci vlastního výzkumného šetření (srov. např. Preissová Krejčí, Cichá, 2011; Preissová Krejčí, Čadová, 2006), ani k lidem s různými fyzickými a mentálními schopnostmi, což mimo jiné dokládá existence praktických základních škol apod. Naopak v české společnosti na základě výše popsané různorodosti, díky letům ekonomické transformace na přelomu 20. a 21. století, nerovnost mezi jejími členy roste. Především se zvyšuje nerovnost $v$ př́stupu ke vzdělání, ale také ke zdravotní péči a $\mathrm{k}$ společenskému statusu i nerovnost mezi rodinami s nízkými a naopak vyššími a vysokými př́ijmy (srov. Šimek, 2013, 135-137; Keller, Tvrdý, 2008, 48-49). Spolu s poklesem rovnosti př́ležitostí a spravedlivého přístupu ke vzdělávání, ale také ke zdravotní či sociální péči narůstá ve společnosti napětí, které $v$ obdobích např. ekonomických krizí může přerůst $v$ občanské nepokoje a celospolečenský konflikt.

Skutečnosti, že také obyvatelé České republiky žijí „ve věku globalizace, v němž se rasové bariéry, stejně tak jako etnické či civilizační vzdálenosti průběžně rozpadají," jak tvrdí Chinaka Samuel DomNwachukwu $(2010,43)$, nelze uniknout. Současně si však spolu s ním musíme uvědomovat, že vznikají bariéry nové, „a sice bariéry rostoucí z ekonomické situace rodin žijících v oddělujících se společenských vrstvách" (DomNwachukwu, 2010, 43). Právě v tomto ohledu je role výchovy k multikulturním hodnotám ve vzdělávání budoucích generací v České republice nedoceněna.

Sociální problémy pojící se s romskou minoritou (chudoba, kriminalita, segregace aj.), jakkoli jsou důležité, na sebe poutají př́lišnou pozornost na úkor aplikace výchovy $k$ toleranci, $k$ pluralitě a $\mathrm{k}$ protipředsudečnému chování $v$ dalších oblastech, ve smyslu prosazování rovného přístupu na základě genderu, sociální vrstvy, zdravotního stavu apod. Pokusíme se toto naše stanovisko níže objasnit a přibližit ideje multikulturního vzdělávání mimo Českou republiku, především ve Spojených státech amerických tak, abychom dosáhli jasnější představy o rozsahu i obsahu multikulturní výchovy. Nebot' pod multikulturní výchovou míníme předně snahu o reformování společnosti $k$ solidaritě, k sociální spravedlnosti a k toleranci. Vycházíme tak mj. ze stejné pozice jako Lenka Gulová $(2012,12)$, která tvrdí, že „multikulturní výchova má značný praktický význam vzhledem k vytváření postojů naší společnosti vůči příslušníkům jiných národů, migrantům apod." a jako taková přispívá k naplňování 
nejobecnějších cílů sociální pedagogiky, a sice zkvalitnit život lidem se sociálním znevýhodněním, vůči nimž se u majority setkáváme s vyšší mírou netolerantního a - vzhledem $\mathrm{k}$ jejich obvyklému původu až rasistického chování.

\section{KONCEPCE MULTIKULTURNÍ VÝCHOVY V USA}

Multikulturní vzdělávání, které se zrodilo v průběhu sociálních bouří v 60. a 70. letech 20. století, je mezinárodním hnutím, které existuje ve všech národech na celém světě (Banks, Banks, 2010, 25). Multikulturní výchova $v$ USA se ve smyslu výchovy $\mathrm{k}$ hodnotám pluralitní demokratické společnosti stala mezi učiteli, na rozdíl od př́stupu českých pedagogů, velmi populární. Pod touto výchovou je pak třeba rozumět specifický přístup, jehož cílem je redukce předsudků a diskriminace znevýhodněných menšin, a naopak rozvíjení sociální spravedlnosti pro všechny skupiny, $v$ důsledku toho pak také zajištění rovných přiležitostí a přístupu $k$ politické $\mathrm{i}$ ekonomické moci všem jedincům napříč různorodými kulturními skupinami (Banks, Banks, 2010, 66).

Z výše uvedeného plyne, že multikulturní přístup ve vzdělávání by měl především zdůrazňovat to, co ve společnosti rozšiřuje rovnost a spravedlnost. Domníváme se, že v tomto pojetí, i když jej není lehké ve vzdělávání naplňovat, může společnosti přinést více výhod než zklamání (srov. Sleeter, Grant, 2009, 229). Multikulturní výchově na českých školách je však dosud vzdálený koncept výchovy, jak jej prezentují např. J. A. Banks a Ch. C. Banksová $(2010,25)$. Podle nich je multikulturní výchova založena předně na tom, že všichni žáci bez ohledu na to, do jaké skupiny patří, at již je rozdělíme dle genderu, etnicity, rasy, kultury, jazyka, sociální třídy, náboženství nebo jejich nadání, resp. výjimečnosti, by ve škole měli zažít rovnost ve vzdělávání. Jinými slovy je třeba její základy postavit na eliminaci toho, že někteří žáci mají na základě určitých zvláštních (převážně vnějších) charakteristik větší šanci na úspěch než jiní. Hlavním cílem multikulturní výchovy je podle citovaných autorů pomoci žákům rozvíjet znalosti, postoje a dovednosti potřebné $\mathrm{k}$ běžnému fungování $v$ rámci jejich vlastních mikrokultur, $v$ makrokultuře země, $v$ niž žijí ( $v$ tomto prípadě Spojených států), a v neposlední řadě také v jiných mikrokulturách, s nimiž se setkávají, i v globálním společenství, jehož jsou součástí (Banks, Banks, 2010, 25).

Problematická na chápání multikulturní výchovy v ČR je mimo jiné představa mnohých pedagogů, že může poskytnout jednoduché odpovědi a rychlá řešení (zejména ve vztahu k „romské otázce“). Multikulturní výchova je ovšem kontinuální proces, nebot', jak je zřejmé, cíle, které se jejím prostřednictvím mají uskutečnit (jako např. rovnost ve vzdělávání a odstranění všech forem diskriminace), nemohou být ve společnosti nikdy zcela naplněny (srov. Banks, Banks, 2010, s. 25).

Domníváme se, že multikulturní výchova, vycházející z vymezení multikulturalismu jako ideje založené na tom, že různé skupiny (etnické, náboženské, kulturní apod.) spolu mohou nekonfliktně a rovnoprávně koexistovat $v$ rámci jedné společnosti, a tedy založená nikoli na prezentování rozdílů mezi kulturami, nýbrž na sebepoznání, porozumění hodnotám vlastní kultury i na mezilidských vztazích, nejen mezi žáky, ale také mezi nimi a jejich učiteli, přispívá k rozvoji empatického a tolerantního myšlení žáků, potažmo studentů. Přirovnání, že „kdyby byly ryby antropology, poslední, co by objevily, by byla voda" (Banks, Banks, 2010, 137), považujeme za více než výstižné. Vždyt' lidé jsou jako ty ryby obklopeni mořem stereotypů a jen málo z nich je schopno vidět vodu, tedy kontext, resp. kulturní pozadí, nebot' pohlceni predsudky se zaměřují pouze na vnější (vzhledové) charakteristiky.

V oblasti aplikace multikulturalismu do vzdělávání v České republice se dosud uplatňuje především klasický model tzv. diferenčního multikulturalismu představující „relativistický přístup, který oslavuje odlišnost, esencializuje kulturu a činí dialog, kompromis a dokonce i překlad značně obtižnými“ (Eriksen, 2012, 241), nebot' kritika, jǐž je rozsáhle podrobován zejména v USA, je v ČR omezena převážně na akademické prostředí. Tento nový typ multikulturalismu, tzv. kritický multikulturalismus, přitom „volá po zásadní rekonstrukci konceptuálních, politických i praktických nástrojů rozvíjených pod 
nálepkou multikulturalismu“ (Hirt, 2005, 13). Kritickým multikulturalismem jako novým př́stupem k multikulturní ideologii, která v předcházejících desetiletích opanovala sociální vědy i školství v USA, se obsáhle zabývají např́klad Stephen May a Christine E. Sleeter (2010). Podle nich se z perspektivy kritického multikulturalismu upřednostňuji ve výchově a vzdělávání ty postupy a metody, které vedou členy majority k přehodnocení problematiky etnicity, ke kritickému pojetí rasy, rasových teorií a k nové konstrukci jejich uvědomění. $K$ hodnotám, jako je lidská hybridita, kosmopolitismus, rovnost a spravedlnost, však žáci nejsou přiváděni formou upřednostňování jinakosti kultur a vyzdvihováním jejich pozitiv či originality, ale naopak pomocí analýzy struktur nerovných mocenských vztahů a role institucionalizované nespravedlnosti ve vlastní společnosti (více in Preissová Krejčí, 2014, 53-54).

Je evidentní, že různorodost nespočívá jen v tom, že se odlišujeme (rádoby) rasově, etnicky, kulturně, ale podle anglosaské tradice, respektive americké tradice, také v ostatních prípadech zřejmé odlišnosti od většinové populace. Můžeme pocitovat nerovné zacházení např. ve vztahu $k$ našemu genderu, k naší sexuální orientaci, sociálně-ekonomické třídě, $k$ našemu náboženskému přesvědčení, zdravotnímu handicapu (např. máme-li tělesné postižení), rozdílnému životnímu stylu či $k$ našemu původu a našim zvykům (např. pocházíme-li z venkova) atd. Jsme přesvědčeni, že úsilí o vnášení tolerance a pochopení k odlišným (a většinou slabším) členům společnosti je jedním ze společenských úkolů edukačního procesu.

\section{ROLE PEDAGOGA VE VÝCHOVĚ K TOLERANCI ODLIŠNOSTI}

V souladu s názory Christine E. Sleeterové a Carla A. Granta si jsme vědomi pozitivních změn, které $\checkmark$ oblasti diskriminace a sociální spravedlnosti přinesla poslední desetiletí. Američtí autoři připisují zásluhy na těchto změnách předně dlouhodobému působení pedagogů, kteří ve spojení s komunitními a sociálními hnutími mohou aktivně přispívat $\mathrm{k}$ tomu, „aby se školy, prípadně další sociální instituce, stávaly spravedlivějšími a lépe reagovaly na potřeby svých studentư“ (Sleeter, Grant, 2009, 32-33).

Nebot škola (jako instituce) odráží obecné vzorce společenské diskriminace, učitelé by měli být s to je rozkrýt a přimět žáky $\mathrm{k}$ přehodnocování jejich pohledu na jednotlivé diskriminované skupiny na základě nových poznatků, osobních zkušeností, vcítění, tolerance a solidárního přístupu. Multikulturní výchova může napomoci k reformě výchovně-vzdělávacího procesu se zřetelem $\mathrm{k}$ budování nejen kognitivních, ale také emočních dovedností vedoucích k vnímání školy jako sociálního systému, v němž jsou všechny jeho hlavní proměnné úzce propojeny s cílem zajistit rovné podmínky v dosahování studijních výsledků u studentů různé „rasy“, kultury, náboženství, pohlaví či společenské vrstvy. Stereotypy a předsudky o "těch druhých“ zakořeněné $v$ ",tradiční americké společnosti“ pak mohou učitelé s pomocí studentů v kulturně diverzitních třídách částečně odbourat přibližením kulturně odlišných prostředí, z nichž jejich žáci pochází, pomocí konkrétních př́kladů (Banks, Banks, 2010, 22-23), k jejichž popisu přispějí sami žáci, za současného vytvoření atmosféry empatie a tolerance, tedy ve smyslu zprostředkování zkušenosti s příslušníkem nějak odlišné skupiny a zároveň náležejícího do stejné skupiny jako ostatní žáci (tř́ídní kolektiv).

Popsaná problematika je spojena s moderní společností v USA dlouhodobě, a proto se zde také učitelé obvykle dělí na ty, kteří multikulturní vzdělávání podporují, a na jeho odpưrce, nebot' je zřejmé, že ani zde se nesetkáme s jednohlasným přijetím multikulturalismu všemi pedagogy. Nejčastěji je možno rozčlenění pedagogů dle jejich př́stupu k multikulturnímu vzdělávání pozorovat na způsobu jejich interpretace odlišnosti u žáků. Zatímco jedni k ní přistupují coby $\mathrm{k}$ jejich nedostatku, druzí naopak v odlišnosti žáků se projevující lidskou variabilitu oceňují.

V průběhu let byly vytvořeny speciální vyučovací strategie napomáhající lišícím se žákům $v$ jejich zapojení do běžného fungování majoritní společnosti, přičemž jsou zohledňovány nejen děti imigrantů, ale také děti chudé, děti, jejichž rodiče nemají práci nebo jsou jinak sociálně-ekonomicky znevýhodněné, či děti zdravotně postižené. 
Chinaka Samuel DomNwachukwu rozlišuje dva typy učitelů na základě jejich přístupu $k$ žákům, kteří pochází z řad migrantů, tedy k nováčkům v americké společnosti. První skupinu bychom mohli označit jako učitele „asimilátory“, druhou pak představují učitelé v roli „pana domácího“.

Ideologie asimilace, pod níž rozumíme proces, $v$ jehož průběhu si člověk přisvojuje chování, hodnoty, víru a životní styl dominantní kultury (DomNwachukwu, 2010, 62), byla v americké historii charakteristická pro období od počátku 20. století po první světovou válku. Tehdy se anglosaská protestanská kultura stala dominantní americkou kulturou, jejiž ideou bylo, aby se imigranti vzdali svých etnických charakteristik a príjali dominantní kulturu. $V$ pedagogickém procesu se upřednostňoval př́stup vedoucí k eliminaci originálních vlastností etnických minorit a k osvojení anglosaských hodnot a způsobů chování. Jeden z představitelů tehdejší odborné pedagogické veřejnosti Elwood Patterson Cuberly uvedl za cíl školního vzdělávání tento: „Naším úkolem je tyto skupiny nebo osady rozbít, tyto lidi asimilovat, aby se stali součástí naší americké rasy, vštípit do jejich dětí, pokud to bude možné, anglosaskou koncepci spravedlnosti, zákona a rádu a probudit $v$ nich úctu $\mathrm{k}$ našim demokratickým institucím a $\mathrm{k}$ těm věcem $\mathrm{v}$ našem národním životě, kterých si jakožto lidé trvale vážíme" (In DomNwachukwu, 2010, 62). Asimilační perspektiva, která charakterizuje dodnes první typ učitelů ve Spojených státech, tak má kořeny na prahu 20. století a ukazuje, že redefinování cílů pedagogického procesu je pro 21 . století opodstatněné a že výchova k multikulturním souvislostem zaujímá ve školním kurikulu nepostradatelné místo.

Druhý jmenovaný typ, učitel v roli pana domácího, nevykonává nad žáky z řad migrantů tzv. kulturní policii (což je charakteristické pro asimilační strategii prvního typu učitelů), nýbrž se nachází v roli př́tele, spojence studenta na cestě $\mathrm{k}$ jeho seberozvoji a seberealizaci. Že toho Ize dosáhnout, demonstruje DomNwachukwu na modelové projektové hodině, kterou nazval Kdo jsem já ve své kultuře? V ní je žákům poskytnut prostor a čas pro objevování vlastního kulturního dědictví, stejně tak jako prejatých kulturních vlivů, aby byli následně vedeni $k$ pochopení toho, kým jsou, a $k$ uvědomění toho, co představuje jejich kulturu. Autor tvrdí, že lidská diverzita, která se vynoří po zodpovězení těchto otázek ve třídě, může být fascinující (DomNwachukwu, 2010, 7). Je prokazatelné, že takový přístup nevede $\mathrm{k}$ vytváření či upevňování stereotypních představ o určité skupině lidí ani ke stigmatizaci žáka, ale naopak k vykreslení jeho individuálních znaků a $\mathrm{k}$ specifikaci lidské odlišnosti $v$ multikulturní třídě, a $v$ důsledku tedy podporuje individuální přístup ke každému z žáků. Právě $v$ takovém postupu spatřujeme smysl multikulturní výchovy, který by měl nalézt své uplatnění také v českém školství.

Nelze tvrdit, že také současná česká společnost necítí potřebu vnést toleranci a pochopení k odlišným členům společnosti do edukačního procesu. Rovněž v České republice se cíle edukačního procesu v souladu s reformou vzdělávání postupně přesouvají od snahy o předání co největší standardizované sumy znalostí k úsilí rozvinout u žáků takové kompetence a dovednosti, které by jim umožnily prožití jejich životů jako plnohodnotných členů společnosti. $V$ souladu $s$ výše uvedeným považujeme za zásadní krok správným směrem právě proměnu metod výuky. Na zavedení informačních a komunikačních technologií do výuky $v$ předchozím desetiletí navazuje $v$ současné době realizace velkého množství projektů (mimo jiné i díky finanční podpoře z ESF) doprovázejících zavádění změn prostřednictvím školské reformy. Učitelé jsou vedeni (či okolnostmi nuceni) k opouštění klasických vyučovacích metod a organizačních forem výuky i k opouštění akcentu na disciplínu a pořádek. Tím se samozřejmě proměňuje i jejich role, jejíž přijetí může být pro mnohé z nich komplikované. Pedagogové jsou totiž stále méně vnímáni jako zprostředkovatelé znalostí a spiše jsou považováni za určité průvodce žáků na jejich cestě za poznáním, přičemž jsou vyzdvihovány především jejich „koučovské dovednosti“" (srov. Kotrba, Lacina, 2011, 21-28). Také my jsme přesvědčeni, že vzdělávání, které vede žáky pouze $\mathrm{k}$ měřitelným výsledkům a které sleduje jen vzdělanostní př́růstek, je nedostatečné ( $\mathrm{v}$ letech 2010-2013 jsme skrze projekt ESF OP VK „Multikulturní workshopy“ sami participovali na zavádění multikulturního vzdělávání do škol, více např. Preissová Krejčí et al., 2012; Preissová Krejčí, Šotola, 2012; Preissová Krejčí, Švachová, 2013). Vždyt' největší světové konflikty nebyly způsobeny negramotnými lidmi, ale těmi, kteři bez ohledu na původ, rasu, náboženství apod. nebyli schopni spolu 
vycházet a společně přispět $\mathrm{k}$ řešení konfliktů či celosvětových problémů (jako např. globálního oteplování, epidemie HIV/AIDS, chudoby, terorismu, válek apod.) (srov. Banks, Banks, 2010, 22-23). Domníváme se proto, že vzdělání musí být vyvážené jak po stránce kognitivní a psychomotorické, tak po stránce afektivní. Pouhé znalosti o odlišných kulturách $v$ nás jen stěží rozvinou empatické porozumění a toleranci odlišných zvyků, životního stylu apod.

V letech 2010-2012 jsme uskutečnili výzkumné šetření mezi českými adolescenty, které odhalilo tendence ke xenofobnímu způsobu uvažování a k rasistickým projevům, navzdory skutečnosti, že procentuální zastoupení cizinců a národnostních menšin na české populaci nasvědčuje spiše tomu, že pravděpodobnost setkávání se s odlišnou kulturou je minimální (srov. Preissová Krejčí et al., 2012). Kde se tedy v naší společnosti berou předsudky a předpojaté jednání vůči cizincům, migrantům, zástupcům menšin? Právě hodnotová orientace dospívajících, nebot' odráží hodnoty a přesvědčení celé české společnosti, nám může pomoci pochopit zdroje, z nichž vychází xenofobní způsob uvažování a rasistické projevy většinové populace. Pod pojmem hodnoty rozumějme jedincem upřednostňované přesvědčení a ideje, vnitřní a subjektivní, založené na tom, jak vidí svět. Postoj pak je určité přesvědčení, které jedinec sdílí po delší čas, respektive často od jeho nabytí až do konce života. Podle DomNwachukwua $(2010,45)$ je nesporné, že hodnoty a postoje vznikají nejen na bázi osobní zkušenosti, ale že jsou neméně často vytvářeny také výchovou, tedy jsou kulturně determinovány. To jasně dokládá nepopiratelný vliv školy, resp. pedagogů, na postoje žáků zaujímané k jedincům nějak odlišným. Dodejme, že výsledky našeho výzkumu mj. odhalují, že otázky vázané na multikulturalismus, pluralismus a toleranci jsou gymnazisty, stejně jako mnohými pedagogy, nepřehlédnutelně „zploštěny“ na tzv. romskou otázku. Respondenti romskou menšinu komentovali a hodnotili mnohem častěji než cokoli/kohokoli jiného, a to i v průběhu námi realizovaných multikulturních workshopů, přestože jsme se snažili primárně akcentovat zcela jiná témata (více In Preissová Krejčí, Cichá, 2014; Preissová Krejčí et al., 2012).

\section{RASA JAKO BĚŽNÝ POJEM Z UČEBNIC}

„Multikulturní výchova $v$ současném konceptuálním pojetí z tohoto pohledu spiše podporuje stereotypní utvrzování kategorií kulturních typů a omezuje výčet způsobů mezilidského lišení (Morvayová, Moree, 2009, 13). Je zřejmé, že ve vztahu k cizím kulturám máme tendenci pohlížet na její představitele v kategoriích "my“ a "oni“. Jak upozorňuje Jan Kosek, soužití různých kultur a náboženství vždy souviselo s vnímáním jinakosti a vytvářením stereotypů o nás i o těch druhých (Kosek, 2011, 346). Do určité míry je toto vymezení nezbytné pro vlastní sebe-vědomí (Kosek, 2011, 223). Na druhou stranu je nutné $v$ daném vztahu my-oni nalézt určitou rovnováhu, abychom nepohliželi na ty druhé jako na méněcenné, jako se to $v$ historii lidstva nejednou událo. Dichotomie „my“ a „oni“ akcentovaná v edukativním procesu „fixuje a anticipuje exkluzi těch, kteří jsou zahrnuti do kategorie ,oni“" (Morvayová, Moree, 2009, 13). Přitom stejnost a diference, základní znaky konceptu identity, jsou v souladu s tvrzením Tomáše Hirta sociálními konstrukty (Hirt, 2005, 43). Na vytváření těchto konstruktů pak má hlavní podíl generalizace základních lidských atributů, tedy obvykle viditelných rozdílů odkazujících současně k základním podobnostem mezi lidmi, které jsou neméně často dány sdílenou kulturou. Jak upozorňuje Thomas Hylland Eriksen, lidé jsou právě díky společností sdílené kultuře odlišní (Eriksen, 2008, 13).

Z podobných úvah vychází například Ali Rattansi, který se zamýšlí nad přirozeností rasismu v dějinách. Podle něj je základním postojem mnoha současných rasistů a ultranacionalistů přesvědčení, že to, co kritici odsuzují jako rasismus, je pouze produktem přirozených lidských vlastností. „Těmi jsou např́klad ochota lidských skupin, především ,národů', chránit svůj ,vlastní druh' a svá teritoria, což jako určitá forma sebezáchovy nevyhnutelně zahrnuje obranné chování na základě stereotypů. Ty mohou sice spočívat na omezených znalostech, ale zároveň představují rozumnou opatrnost. Tudíz, co jedni mohou považovat za formu rasismu, je druhými vnímáno jako způsob myšlení a chování, který vychází 
ze ,zdravého rozumu'. Jednat tímto způsobem je pro nás ,přirozené'. Předpokládá se, že díky tomu přežívají jedinci, národy i kultury." (Rattansi, 2007, 126)

Hlavním problémem, jak úvah „zdravého rozumu“, tak i akademických rozprav, které společenské chování vidí výhradně či převážně jako biologicky podmíněné, resp. dané evolučními mechanismy, je, že samy nejsou schopny stanovit, kde a proč jsou určeny hranice jednotlivých skupin. Např́klad na národech a národnostních státech není nic přirozeného, vždyt' vznikly až v moderní době. Tvrdit, že existuje biologická návaznost mezi obranou národního území, zobecněnou xenofobií nebo neprátelstvím k „cizincům" a přirozeným upřednostňováním „svého vlastního druhu“, je zavádějící. „Vlastní druh" může nakonec být i skupina založená na rodu, barvě pleti, náboženství, zaměstnání, ulici, sousedství, vesnici, městě, zemi nebo velkých aglomeracích národů obsažených napríiklad v rámci Evropy či Evropské unie (srov. Rattansi, 2007, 126-127).

Přestože stereotypizace členů skupin a zvýrazňování jejich podobností a jejich rozdílů ve srovnání s jinou skupinou se zdá být více či méně univerzální, nevysvětluje to, proč jsou určitým skupinám připisovány specifické vlastnosti. Předpokládaná nevyhnutelnost rasismu bývá někdy vysvětlována jako produkt dalších druhů vrozených psychologických vlastností lidí. Jedním z nich je hledání tzv. obětních beránků (více in Rattansi, 2007, 127-130).

Všechny výše popsané pohledy mohou v hodinách multikulturní výchovy hrát ústřední roli v přijímání odlišných žáků většinovou skupinou či obecně odlišných jedinců celou společností. Specifickým problémem českého školství je neuvěřitelně ahistorické přijímání dělení lidstva na tři základní rasy, včetně jejich procentuálního zastoupení ve světě, jako přirozené součásti českého vzdělávání. Toho dokladem je přítomnost rozširreného přesvědčení o existenci ras $v$ učebnicích běžně užívaných na českých základních školách, jen pro príklad jmenujme Zeměpis 5 - Hospodárství a společnost (kol. autorů, 2003, 7-8) nebo Prírodopis 8 - učebnice pro základní školy a víceletá gymnázia (kol. autorů, 2006, 51-52).

Podle většinového názoru, žákům českých škol běžně prezentovaného $v$ učebnicích, je rasa jasně ohraničeným souborem fyzických charakteristik (např. fenotypu). Stephen Molnar soudí, že do značné míry je tomu tak proto, že primárně vnímáme viditelné tělesné rozdíly mezi lidmi různého zeměpisného původu, jimž jsme přiřadili na základě podobnosti „nálepky“ jako Asiaté, Afričané nebo Evropané. Nicméně to neznamená, že popsané rozdělení lidí do několika ras je jakkoli užitečným nástrojem pro studium našeho původu či adaptace. Termín „rasa“ je ve skutečnosti pouhý socio-politický konstrukt, jenž navazuje na sociální a historické procesy. Vymezením "rasy“ neobjasníme stupně genetické variability uvnitř lidských skupin nebo mezi nimi. Jak tvrdí Molnar, „ani v minulosti, ani dnes neexistovaly jasně vymezené fyzické či duševní vlastnosti, které by jedné ,rase' byly vlastní a druhé ne. Mezi jednotlivými skupinami obyvatel podle zeměpisného původu nejsou ani absolutní, ani pevné hranice. ,Rasové rozdíly' byly vytvořeny společností, tedy koncept ,rasy“ je sociální a kulturní konstrukcí a je na nás, jak se s ním vyrovnáme“ (Molnar, 2005, 32).

Od nevědeckého označení „rasa“ pro lidské skupiny a populace (více in Jakoubek, 2005, 201, Preissová Krejčí, 2014, 74) je k rasistickému chování mezi členy společnosti jen nevelký krok. Přestože je podle mnohých autorů rasismus těžko definovatelný, je reálně přítomný a vždy zvýhodňuje dominantní skupinu ve společnosti (Banks, Banks, 2010, 185). V současnosti se antropologové ve shodě s genetiky a lékaři domnívají, že odhalená biologická variabilita lidstva a její perspektiva, jak ji demonstruje ve své práci např́klad výše citovaný Molnar $(2005,32)$, je natolik pestrá, že antroporasové teorie a původní eugenické př́istupy $\mathrm{k}$ vymezení etnicity nebo rasy jsou více než překonané.

Nutno dodat, že pod tíhou výše popsaných informací se již v některých vybraných učebnicích hovoří o lidské variabilitě a ve vztahu $\mathrm{k}$ ní autoři od termínu rasa upustili, za všechny takto upravené učebnice jmenujme alespoň Zeměpis 9 - učebnice pro základní školy a víceletá gymnázia (kol. autorů, 2008, 3840). Předpokládáme, že touto cestou naše kurikula a vzdělávací praxe půjdou dále, je nicméně evidentní, že obměna učebnic užívaných při výuce je dlouhodobou záležitostí. Nemluvě o skutečnosti, že první dojem z poslední jmenované učebnice kazí stereotypní prezentace romské menšiny u nás, 
která zdůrazňuje problematičnost této „svérázné etnické skupiny, která má svůj jazyk (romštinu), své tradice, historii, specifické způsoby organizace společnosti, ale také tělesné a psychické zvláštnosti“ (Zeměpis 9, 2008, 41), čímž její členy odlišuje od „nás“ a současně z nich vytváří homogenní skupinu.

\section{MÍSTO ROMSKÉ OTÁZKY V MULTIKULTURNÍ VÝCHOVĚ}

Ve společnostech, které jsou dlouhodobě diferentní a které dokonce staví část své národní identity na uznání rozdílnosti, je multikulturní vzdělávání dlouhodobě koherentní součástí školních kurikul (př́kladem mohou být USA, Kanada, Mexiko aj.). Naopak v posttotalitních společnostech, které dlouhodobě směřovaly $\mathrm{k}$ národní identitě spojené $\mathrm{s}$ jednotnou ideologií, se multikulturní prístup ve vzdělávání paralyzuje na zástupné problémy (příkladem může být ČR, Slovensko, Ukrajina aj.), at již jde o spojení s folklórem, či s problematickou menšinou. $V$ naší společnosti je takovýmto pseudoproblémem problém menšiny romské, jak jsme naznačili již výše. Zdá se, že co do iniciace společenských problémů $v$ jejich soužití $s$ majoritní populací odpovídá romská menšina $v$ ČR afroamerické populaci USA ${ }^{1}$. Toto srovnání není z mnoha důvodů přesné, jedni i druzí se nicméně stali zástupným problémem, jakýmsi společenským „hromosvodem“, a multikulturní vzdělání se díky problémům, které jsou s nimi spojené, $v$ našem prostředí stále chápe jako prostředek řešení etnické otázky. Ta však ve skutečnosti tvoří jen jeho marginální část.

Jinými slovy, v České republice směřování multikulturalismu k „romské otázce“, respektive k problematice etnické př́slušnosti, koresponduje s obecným pojímáním multikulturního vzdělávání, $v$ němž jsou opomíjena témata jako např. sociální status, gender, zdravotní postižení apod. Naše praktická zkušenost i výsledky výzkumných šetření, na které se v textu odkazujeme, potvrzují názor, který zastává mj. Ivan Ramadan. Podle něj se zavedením multikulturní výchovy do vzdělávacích programů zviditelňuje, udržuje a posiluje vnímání odlišnosti Romů. „Tato akcentace odlišnosti je v úzkém spojení s důrazem na ,etnicitu' Romů či jejich ,národní identitu'a znamená vyčleňování určité ,skupiny', která vyžaduje zvláštní opatření." (Ramadan, 2008, 193) Více než co jiného se může jednat o jednu z forem praktické politiky - praktického komunitarismu. Politiky poplatné etnopolitickým a etnorevitalizačním hnutím, připomínající politiku nacionálních hnutí, mají za cíl tvorbu představy existence „romské etnické identity“. Touto studií jsme se snažili poukázat na skutečnost, že multikulturní výchova by z výše uvedených důvodů neměla za svůj středobod považovat „romský problém“. Takto vedená praktická politika totiž ve svém důsledku přispívá nikoli k jeho řešení, ale ke spojování negativních sociálních jevů s Romy jako představiteli skupinové identity. Uplatňování principů individualizace namísto etnické či kulturní identity by přitom mohlo vést $k$ odstranění stigmatizace Romů (ale také zástupců dalších minorit) a v důsledku toho nabídnout možnosti, jak předejít jejich sociálnímu vyloučení (Ramadan, 2008, 178-207).

Obdobně smýšlí také Anne Phillips $(2009,162)$, která je přesvědčena, že by se multikulturalismus, jenž obhajuje, měl zasazovat za práva jedince, nikoli skupiny. „Jedinci jsou v minoritních skupinách opomíjeni a není slyšet jejich názor." (Phillips, 2009, 161) Minority jsou na veřejnosti zastupovány jednotlivci jako svými představiteli, kteří prezentují názory své nebo jim blízké části minoritní komunity, jako by to byly názory všech jejích členů. $V$ rámci komunální politiky, př́padně veřejné správy, se informace členům minoritních skupin předávají právě prostřednictvím takto vybraných zástupců. Ovšem tito představitelé minoritních skupin, byt' u určité části komunity mohou mít uznání, jsou velmi často konzervativní a jejich společenský status není sdílen celou komunitou. Kulturu nelze charakterizovat jen dle většinově sdílených tradic, zvyklostí a přesvědčení a multikulturalismus není nástrojem, $\mathrm{s}$ jehož pomocí se má dělit moc mezi různé subkultury a jejich představitele. Jak uvádí Phillips, multikulturní problematika je blokována přehnaně holistickým přistupem ke kultuře, $v$ důsledku čehož se dílčí problémy vyskytující se v minoritních skupinách generalizují na všechny jejich

\footnotetext{
${ }^{1}$ Nabízí se také srovnání s celospolečenským klimatem a se sociálními problémy (chudoba, nízké vzdělání apod.) v soužití majority s minoritou v mexické společnosti (srov. Erdösová, Madrazo, 2013, 47-60).
} 
členy. Tak upozorňuje např. na to, že britská vláda teprve po bombovém útoku v roce 2005 začala hovořit o britských muslimských komunitách v plurálu a uznala, že je velmi zavádějící předpokládat, že všichni britští muslimové patři do jediné unifikované kultury, tedy že všichni britští muslimové sdílí stejný názor např. na manželství, vraždu pro zachování cti, ženskou obřízku (z morálních a náboženských důvodů ve Velké Británii od roku 1985 zakázanou) nebo nošení šátku (Phillips, 2009, 165 a dále).

\section{ZÁVĚR}

V naší studii jsme reflektovali rizika, která s sebou multikulturní výchova nese, v protikladu k výhodám, o jejichž dosažení usilujeme, i způsoby, jakými lze k obojímu dospět. Pět, respektive sedm, let je poměrně krátká doba na to, abychom činili obecné závěry o vlivu, jaký její zavedení do školní praxe má na hodnoty a postoje žákủ, či o tom, zda skutečně přispívá k vytváření tolerantnějšího a přívětivějšího prostředí pro menšiny u nás žijící. Ve školním prostředí se pohybujeme dlouhodobě jako lektoři multikulturních workshopů a máme prostor diskutovat s pedagogy o jejich pohledu na multikulturní výchovu. Domníváme se, že až dosud bylo poměrně málo pozornosti věnováno právě jejich názorům a postojům, jsou to však především oni, kdo mají cílů výchovy k multikulturalismu dosahovat. Přitom se zdá, že vliv pedagogů na hodnoty a postoje jejich žáků je do velké míry opomíjen. Jak jsme nicméně ukázali, role pedagoga $v$ edukačním procesu je neopomenutelná, stejně jako význam edukačních pomůcek. I proto by měly být principy sociální pedagogiky začleněny do přípravy budoucích pedagogů na všech typech škol.

Jsme přesvědčeni, že důraz na individuální přístup by v řadě případů napomohl prevenci stereotypizace menšin a předsudečného chování veřejnosti směrem $k$ členům minoritních skupin. Ve výše popsaných prípadech je pak individuální přístup $k$ zástupcům minoritních skupin předpokladem nejen k plnohodnotnému prožití jejich životů, ale obecně k zachování bezpečnosti a rozvoje multikulturních společností (tedy, jak pevně věříme, i společnosti naší), proto by $k$ němu měli být žáci vedeni nejen $v$ rámci multikulturní výchovy, ale tento přistup by se měl také v České republice stát imanentní součástí edukačního procesu jako takového.

\section{LITERATURA}

Banks, J. A., \& Banks, Ch. A. M. (2010). Multicultural Education: Issues and Perspectives. New York: John Wiley \& Sons.

DomNwachukwu, Ch. S. (2010). An Introduction to Mulicultural Education: From Theory to Practice. Lanham: Rowman \& Littlefield Publishers.

Erdösová, Z. \& Madrazo Miranda, M. (2013). Vzdělávání v multikulturních společnostech: Mexický interkulturní bilingvní model a socioekonomické podmínky mexických indiánských národů na prahu 21. století: nerovnost a chudoba. In A. PREISSOVÁ KREJČí. \& R. JUÁREZ TOLEDO, et al. Sociální exkluze $v$ multikulturních společnostech. Komparace současné situace $v$ České republice a v Mexiku. (s. 47-60). Olomouc: Univerzita Palackého.

Eriksen, T. H. (2012). Etnicita a nacionalismus. Antropologické perspektivy. Praha: SLON.

Eriksen, T. H. (2008). Sociální a kulturní antropologie: príbuzenství, národnostní příslušnost, rituál. Praha: Portál.

Gulová, L., et al. (2012) Aktivizace sociálně znevýhodněných skupin v pedagogické praxi a výzkumu. Brno: MU.

Hirt, T. (2005). Svět podle multikulturalismu. In T. HIRT \& M. JAKOUBEK, et al. Soudobé spory o multikulturalismus a politiku identit. Plzeň: Nakladatelství Aleš Čeněk. 
Jakoubek, M. (2005). Multikulturalizmus vs. kultura. In T. HIRT \& M. JAKOUBEK, et al. Soudobé sporyo multikulturalismus a politiku identit. Plzeň: Nakladatelství Aleš Čeněk.

Keller, J., \& Tvrdý, L. (2008). Vzdělanostní společnost: chrám, výtah a pojištóovna. Praha: SLON.

Kolektiv autorů. (2003). Zeměpis 5 - Hospodářství a společnost. Olomouc: Prodos.

Kolektiv autorů. (2006). Př́rodopis 8 - učebnice pro základní školy a víceletá gymnázia. Plzeň: Fraus.

Kolektiv autorů. (2008). Zeměpis 9 - učebnice pro základní školy a víceletá gymnázia. Plzeň: Fraus.

Kosek, J. (2011). Právo (n)a předsudek. Historické, filozofické, sociálně psychologické, kulturní a právnické souvislosti stereotypů a predsudků. Praha: Dokořán.

Kotrba, T., \& Lacina, L. (2011). Aktivizační metody ve výuce - Př́ručka moderního pedagoga. 2. vyd. Brno: Barrister \& Principal.

May, S., \& Sleeter, Ch. E. (2010). Critical Multiculturalism. New York: Routledge.

Molnar, S. (2006). Human Variation: Races, Types, and Ethnic Groups. New Jersey: Pearson Prentice Hall.

Morvayová, P., \& Moree, D. (2009). Dvakrát měř, jednou řež: od multikulturní výchovy ke vhledu. Praha: Člověk v tísni.

Phillips, A. (2009). Multiculturalism without Culture. Princeton: Princeton University Press.

Preissová Krejčí, A. (2013). Multikulturní koncept ve vzdělávání a výchově v České republice. In A. PREISSOVÁ KREJČí \& R. JUÁREZ TOLEDO, et al. Sociální exkluze $v$ multikulturních společnostech. Komparace současné situace $v$ České republice a v Mexiku. (s. 11-45). Olomouc: Univerzita Palackého.

Preissová Krejčí, A. (2014). Multikulturalismus - ztracené paradigma? Olomouc: Univerzita Palackého.

Preissová Krejčí, A., \& Čadová, L. (2006). Hodnocení morálky, životních cílů a postojů u vybraného okruhu dospívající mládeže v Olomouckém a Zlínském kraji - „zpráva z realizace rozvojového projektu“. E-Pedagogium, 1, 57-70.

Preissová Krejčí, A., \& Cichá, M. (2011). Hodnotové orientace adolescentů v České republice a ve středním Mexiku. (Výběr z komparativní studie). Paidagogós, 2, 71-101.

Preissová Krejčí, A., \& Cichá, M. (2014). Multikulturní vzdělávání jako zdroj duchovních hodnot v odborné př́ípravě a vzdělávání pracovníků pomáhajících profesí. Paidagogos, 1, 87-110.

Preissová Krejčí, A., \& Šotola, J. (Eds.), (2012). Metodika pro realizaci multikulturní výchovy formou zážitkové pedagogiky. Olomouc: Univerzita Palackého.

Preissová Krejčí, A., \& Švachová, I. (Eds.), (2013). Protipředsudkové vzdělávání v kontextu multikulturalismu. Olomouc: Univerzita Palackého.

Preissová Krejčí, A., Cichá, M., \& Gulová, L. (2012). Jinakost, předsudky, multikulturalismus: Možnosti a limity multikulturní výchovy. Olomouc: Univerzita Palackého.

Procházka, M. (2012). Sociální pedagogika. Praha: Grada.

Ramadan, I. (2008). Multikulturní politika České republiky ve vztahu k „romské komunitě“. In M. JAKOUBEK \& L. BUDILOVÁ (Eds.), Romové a cikáni - neznámí i známí. (s. 194-195). Voznice: Leda.

Rattansi, A. (2007). Racism: A Very Short Introduction. Oxford: Oxford University Press.

Sleeter, Ch. E., \& Grant, C. A. (2009). Making Choices for Multicultural Education. Five Approaches to Race, Class, and Gender. New York: John Wiley \& Sons. 
Šimek, D. (2013). Reflexe sociální exkluze v integrální andragogice - zdroje a přístupy. In A. PREISSOVÁ KREJČí \& R. JUÁREZ TOLEDO, et al. Sociální exkluze v multikulturních společnostech: komparace současné situace $v$ České republice a $v$ Mexiku. Olomouc: UP.

Viktorová, B. (2013). Realizace multikulturní výchovy na základních školách v okrese Karviná. Bakalářská práce. Olomouc: Univerzita Palackého v Olomouci, Filozofická fakulta. Vedoucí práce: Andrea Preissová Krejčí.

\section{Autor}

Mgr. Andrea Preissová Krejčí, Ph.D., Univerzita Palackého v Olomouci, Filozofická fakulta, Katedra sociologie, andragogiky a kulturní antropologie, Tř. Svobody 26, 77900 Olomouc, e-mail: andrea.krejci@email.cz

Mgr. Jana Máčalová, Univerzita Palackého v Olomouci, Filozofická fakulta, Katedra historie, Na Hradě 5, 77900 Olomouc, e-mail: jana.macalova@gmail.com

Text této studie vznikl díky projektu Za hranice multikulturalismu. Filozoficko-pedagogické aspekty multikulturního vzdělávání? podpořeného na Filozofické fakultě Univerzity Palackého v Olomouci v roce 2014 z Fondu pro podporu vědecké činnosti.

\section{Boundaries of a Czech multicultural education}

Abstract: This article is a critical review of the Czech approach to multicultural education. Using as an example the American multicultural educational system, we illustrate the narrow understanding of the content of multicultural education in the Czech Republic and Czech schools. We also point out the problematic moments which not only obstruct the successful fulfillment of educational goals, but may also strengthen or even create a stereotypical, xenophobic or racist environment in classrooms. The significant agents in this process are considered to the teachers on the one hand, and on the other the conceptualization of a specific vocabulary used in many textbooks, which is typical for racist and nationalist movements.

Keywords: multicultural education - Czech Republic, multicultural education - USA, teacher, race, ethnicity 